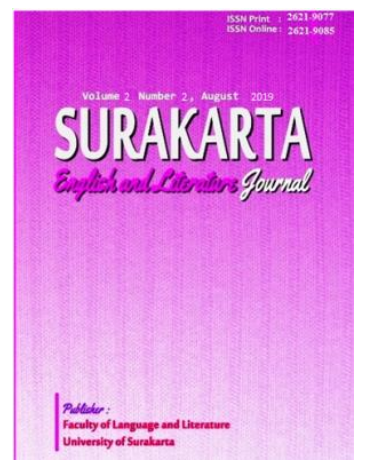

SURAKARTA ENGLISH AND LITERATURE JOURNAL

\title{
QUALITY ASSESSMENT OF ONLINE SERVICES IN THE HEALTH ARTICLE SDL FREE TRANSLATE VERSUS TRADUKKA
}

\author{
${ }^{1}$ Ika Oktaria Cahyaningrum, ${ }^{2}$ Yunita Widiyantari
}

Faculty of Language and Literature, University of Surakarta. ikaoktaria1@ gmail.com Faculty of Language and Literature, University of Surakarta. widiyantariyunita@gmail.com

\begin{abstract}
This study discusses the translation quality comparison produced by SDL Free Translate and Tradukka online translation services. This study includes qualitative descriptive research which is using discussion methods, questionnaires and interviews. The result of this study is the quality of the translation produced by Tradukka is more accurate, acceptable and readable than SDL Free Translate. It can be showed by percentage of $9.8 \%$ for the quality of SDL Free translations and $11.3 \%$ for translations produced by Tradukka. From the results of the analysis found that not all of online translation services have good translating capacity. It is based on the quality of the translation produced between the two online translation services above.
\end{abstract}

Keywords: Quality Assessment, Online Services, Accuracy, Acceptability and readability.

\begin{abstract}
ABSTRAK
Penelitian ini membahas perbandingan kualitas terjemahan yang dihasilkan oleh layanan terjemahan online SDL Free Translate dan Tradukka. Penelitian ini termasuk penelitian deskriptif kualitatif yang menggunakan metode diskusi, kuesioner dan wawancara. Hasil dari penelitian ini adalah kualitas terjemahan yang dihasilkan oleh Tradukka lebih akurat, dapat diterima dan dapat dibaca daripada SDL Free Translate. Dari hasil penelitian diperoleh persentase sebesar 9,8\% untuk kualitas terjemahan Gratis SDL dan 11,3\% untuk terjemahan yang dihasilkan oleh Tradukka. Dari hasil analisis ditemukan bahwa tidak semua layanan terjemahan online memiliki kapasitas terjemahan yang baik. Ini didasarkan pada penilaian kualitas terjemahan yang dihasilkan oleh dua layanan terjemahan online di atas.
\end{abstract}

Katakunci: Penilaian Kualitas, Layanan Online, Akurasi, Penerimaan dan keterbacaan.Abstrak Bahasa Indonesia 


\section{INTRODUCTION}

Along with the increasing demand for translation services, it also influences the quality of translators. In fact, the limitations of a professional translator are a major problem in the world of translation, in addition to money and time factors as well.With the rapid development of technology, making IT companies also compete in making an innovation in the world of translation. Therefore, there are many online translation services that are very easy to access, equipped with financing that can even be accessed free of charge for all users of translation services. The use of translation engines is growing rapidly through a software used in online translation services. Herry Sujaini in Jurnal ELKHA Vol.6, No 2, said that "Machine translator (MP) is a machine that can do the translation process from one language to another language automatically. MP has practical uses because it can help humans communicate with each other in different languages. This issue is even more important in the current era of globalization, when manual translation by humans has limited and expensive resources". There are many online translation services such as Google Translate, SDL Free Translation, Traddukka, Nice Translator, BabelXL, Frengly and others.However, not all online translation services have a good level of translation quality. In terms of accuracy, acceptance and legibility, a research should be held with the aim of knowing the quality results obtained.

Based on the above problems, the field of this research is in translation quality assessment. The researcher took two online translation services and analyzed more deeply about the quality of the translation and the impact obtained from the quality of the translation itself. In this research, focus of the object of the research is the online translation products. Researcher took two research objects from online translation services namely SDL Free Translate and Tradukka as objects, while the data source was obtained from a health article entitled "Vaginal Birth After Caesarean" by Hannah Dahlen ". This article was taken from a health page named "Pregnancy Birth and Beyond",www.pregnancy.com.au/birth-choice/vbac/vbac-articles/vaginal-birth-aftercaesarean.shtml. Limitation of the research is only focused on the assessment of the translation quality in accuracy, acceptability and readability.

Related research as a reference material is from research conducted by Prakosa (2016) with the title An Analysis on Translation Technique and Translation Quality Of Medical Terms In An Article Entitled "Critical Illness Due To 2009 A / H1n1 Influenza In Pregnant And Postpartum Women: Population Based Cohort Study "Produced By Google Translate. The object of this study focuses on the quality of the translation produced by Google Translate as the largest producer owned by Google companies. This research only focuses on health terms. The second researcher is Novia Arifatun, et al (2012) in Journal of Arabic Learning and Teac Vol.2, Number 1. Her research discusses about "Mistake Translation of Indonesian Text to Arabic through Google Translate (Study of Syntactical Analysis)". The focus of this research is an online translation service from Google Translate, this study aims to determine the accuracy of Google translate in the process of translating texts into Arabic Indonesian and describe the errors that dominate the object of study investigators. This study is expected to provide benefits to the students of the Arabic language in order to minimize the use of Google translate and considering the translation results, especially in terms of the structure of the grammar.

\section{Surakarta English and Literature Journal}


Larson (1984: 17) views translation as a process of transferring mandate from source language text to target language text by using grammatically and lexically form the appropriate target language. Almost the same as the definition of translation according to Nababan (2003: 19-20) that translation not only diverts messages but also forms of language, both literary translators or translators of scientific works need to consider not only the content of the news but also the form of language in translation because in essence each the field of science has a style of language in expressing it.

From the various definitions of translation above, it can be concluded that translation is the process of transferring messages from source languages to natural equivalents as close as possible to the target language by paying attention to the language style.

Ellis Horword(in Prakosa, 2016: 12) in his book series in computers and their application said machine translation is a computer application that can translate a text from one natural language to another. In his opinion the translation machine must be seen as a tool that can ease the translator in terms of time and cost.

Whereas in the opinion of Hutchin (in ELLiCProceding 2018: vol:2) said that the translation of machine is "computerized systems responsible for the production of translations with or without human assistance". This means that a translation machine can produce translations and process all translation data without human intervention.

It can be concluded that the Machine Translator (MT) is the process of translating language from one language to another by using a computer system automatically. This is an advanced and modern breakthrough, so that translation service users are more facilitated and efficient, especially in time and cost.

There are several obstacles to the success of MT including like words with many meanings, sentences with many grammatical structures, uncertainty about pronouns that refer to who, and other grammatical problems. Hence that in the delivery of the message is not right, there is an addition or subtraction of information which results in poor translation quality.

\section{RESEARCH METHOD}

Focus of this study is to investigate the translation technique and translation quality in the article produced by online services (Google Translate, SDL Free Translation and Tradukka). Based on the definition of Oxford Learners Dictionary (in Mudjia Rahardjo, 2017:2), the research used descriptive-qualitative approach with case study design for single case. Single case study is a series of scientific activities carried out intensively, in detail and in-depth about a program, event, and activity, both at the level of individuals, groups of people, institutions, or organizations to gain in-depth knowledge about the event. The data used in this research was an online article entitled "Vaginal Birth After Caesarean". Objective data was collected using a selective note taking technique (criterion-based selection). While affective data collected through the provision of questionnaires to informants with interviews. There is a scale of assessment on the questionnaire distributed to the rater, in which a rater must provide an assessment scale supplemented by the reasons underlying the assessment. While in the assessment of the quality of translation used scale assessment that refers to the theory of Nababan (2010).There are three types of questionnaires used, namely: (1) Accuracy Rating Instrument to measure the accuracy of messages, (2) Acceptability Rating Instrument to measure the acceptability level of translation, and (3) Readability Rating Instrument, to

\section{Surakarta English and Literature Journal}


measure the level of translation legibility.

The design of this study refers to the problem formulation of translation quality generated on Google Translate, SDL Free Translation and Tradukka In A Health Article entitled "Vaginal Birth After Caesarean 'by Hannah Dahlen

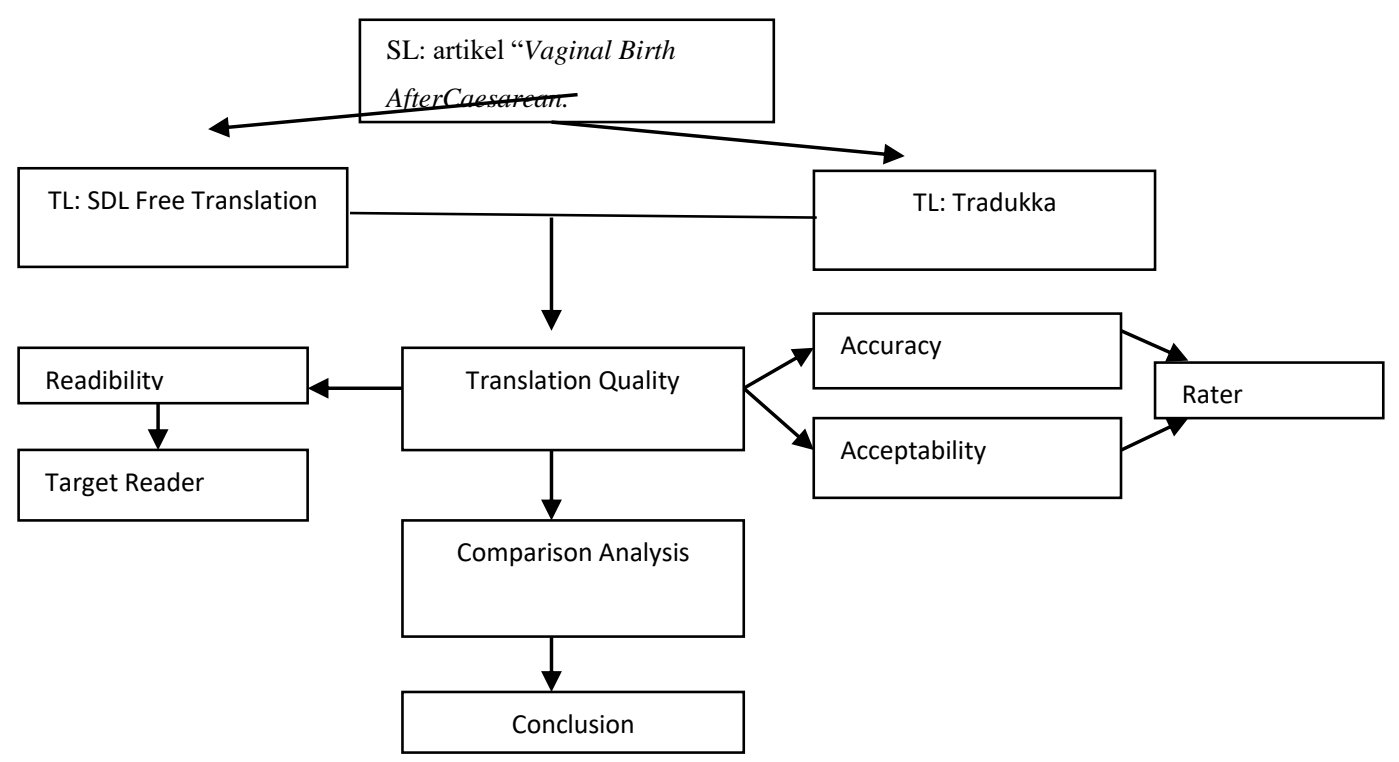

Figure 1. Research Design

\section{FINDING AND DISCUSSION}

\section{FINDING}

From the assessment results obtained from Rater regarding the quality of accuracy, acceptability and quality of readability obtained from the target reader or target audience, it can be explained through the table below:

Table 1. Percentage of Quality of Online Translation Services

\begin{tabular}{llll}
\hline $\begin{array}{l}\text { Ontine services } \\
\text { Quality }\end{array}$ & SDL Free Translate & Tradukka \\
\hline Accuracy & 65,6 & 75,5 \\
Acceptability & 64,9 & 75,5 & \\
Readability & 66 & 75,5 & \\
Total (\%) & $9,8 \%$ & $11,3 \%$ & \\
\hline
\end{tabular}

In this study, the focus of the research object is to use two translation services namely SDL Free Transalation and Tradukka, where each online translation service has nearly the same translation quality. SDL Free Translation has the speed of producing translations that are almost the same as Tradukka. The following is one of the front page presentations on SDL Free Translation and Tradukka's online translation:

\section{Surakarta English and Literature Journal}






Figure 2. SDL Free Translation services

SDL Free translation is equipped with various language sources with various target language sources. It is an unpaid application that can be accessed and used wherever and whenever.

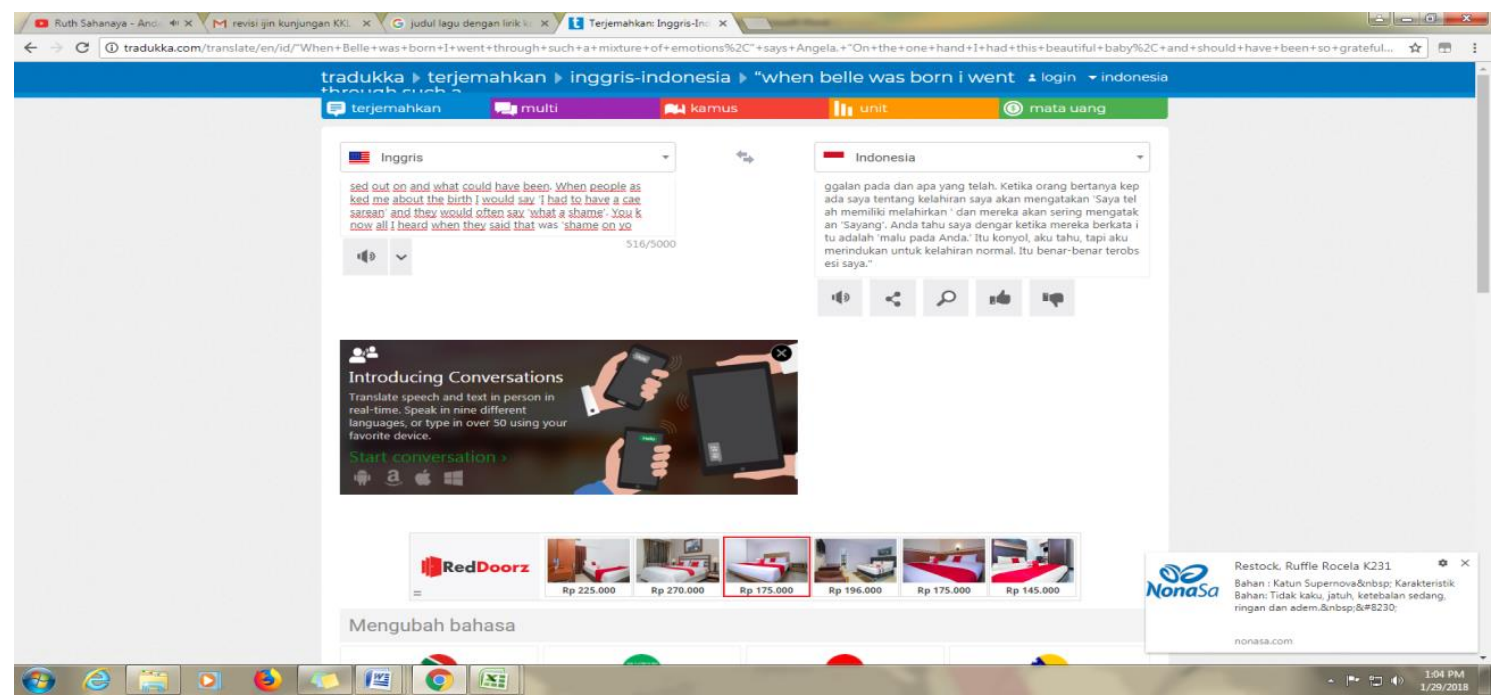

Figure 3. Tradukka services

\section{DISCUSSION}

In Tradukka, it will translate your text and voice in real time. Among the main features will have access to voice recognition, dictionary definitions, text-to-speech for pronunciations, and more than 44 supported languages. Tradukka Translator is a free software application from the Teaching \& Training Tools subcategory, part of the Education category. The app is currently available in English and it was last updated on 2016-05-06. The program can be installed on Android.

Divided into 42 sentence data which is then analyzed into 30 research data, each research data can be in the form of sentence, phrase and word level. From the table 
above it can be concluded that the quality of the translation produced by online translation services from Tradukka is far better than SDL Free Translate. This is because the translation produced by Tradukka at the level of accuracy, the message delivered is more accurate and rarely obtained distortion of meaning, while for the quality of acceptance at SDL free gets a second percentage after Tradukka, the resulting translation feels more natural and there is even a translation translated according to target language culture rules. Readability quality generated by SDL Free Translate, from questionnaires distributed to the target reader, the translation produced by SDL has sufficient quality, this is because most of the text cannot be understood by the reader, there are some words that are not interpreted or not translated so that not all readers are able to read medical terms in the translation. The sub-discussion below is a more detailed discussion of the quality of the translation produced, among others, as follows:

\section{Accuracy}

What is at the core of the assessment of accuracy is the suitability or accuracy of the message conveyed between Bsu and Bsa, whether viewed from the linguistic aspect (grammatical structure), semantics and pragmatic. From the table above, the translation produced by Tradukka has a higher percentage of accuracy compared to SDL Free with an average score of 75.5 .

\section{Accurate Translation}

Accurate translation refers to the level of meaning of words, phrases, clauses, and sentences that are transferred accurately into Bsa. There is no distortion of meaning or ambiguity of meaning in the delivery of messages. There are 15 data from Tradukka, 2 data from SDL Free Translate into accurate translation.

The data below is an example of the quality of translation produced by SDL Free Translate and Tradukka, the level of assessment given by Rater makes the resulting translation quality have an average value of accuracy of 2.6 and 2.8. This can be seen in the table below:

Table 3. SDL Accurate Translation Data Free Translate and Tradukka

\begin{tabular}{llll}
\hline Bsu & \multicolumn{1}{l}{ Bsa SDL free } & BsaTradukka \\
translate & & \\
\hline Data 19/Bsu/Art/28 & Data 19/Bsa/FT/28 & Data 19/Bsa/Trd/29 \\
Just 2 per cent of & Hanya 2 persen & Hanya 2 persen perempuan \\
women perform perempuan melakukan & melakukan latihan dasar panggul \\
pelvic floor exercises & $\begin{array}{l}\text { latihan lantai panggul } \\
\text { tiga kali sehari, tingkat yang }\end{array}$ \\
three times a day, the & tiga kali sehari, & direkomendasikan. (28) \\
recommended level. & tingkat yang \\
$(\mathbf{2 8 )}$ & disarankan. (28) & \\
\hline
\end{tabular}

From the table above it can be seen that the resulting translation quality has almost the same in the target language. Especially on the word "pelvic floor exercises" which translate into latihan lantai panggul and latihan dasar panggul. The transfer of the source language to the target language is largely diverted accurately so that the whole sentence in the target language is understood.

2. Less accurate translation

Inaccurate translations refer to translations in which some of the words, terms, technical, phrases, clauses or sentences of Bsu have been accurately transferred into 
Bsa, but there is still a distortion of meaning or multiple translations (taxa) or there are also omissions of meaning that interfere with the integrity of the message. There are 28 less accurate translation data on SDL Free Translate translation quality and 15 translation data are less accurate on Tradukka translation quality. Assessments for less accurate translation quality have an average value of 2 to 2.5 .

Table 4. Less Accurate Data on SDL Free and Tradukka

\begin{tabular}{|c|c|c|}
\hline Bsu & Bsa SDL Free Translate & BsaTradukka \\
\hline Data 31/Bsu/Art/39 & Data 31/Bsa/FT/39 & Data 31/Bsa/Trd/39 \\
\hline $\begin{array}{l}\text { The majority of } \\
\text { people affected by } \\
\text { incontinence can be } \\
\text { cured or better } \\
\text { managed. (39) }\end{array}$ & $\begin{array}{l}\text { Sebagian besar dari orang- } \\
\text { orang yang terkena } \\
\text { dampak oleh mengompol } \\
\text { dapat disembuhkan atau } \\
\text { dikelola lebih baik. (39) }\end{array}$ & $\begin{array}{l}\text { Mayoritas orang-orang yang } \\
\text { terkena inkontinensia dapat } \\
\text { disembuhkan atau lebih } \\
\text { berhasil. (39) }\end{array}$ \\
\hline
\end{tabular}

The translation feels stiff and the message conveyed is a distortion of meaning can be found in the quality of SDL Free Translate translation. The word "incontinence" is translated into Bsa to "wet the bed". In terms of legibility, it is easier for readers to understand medical terms, but judging from the equivalent level of words, the word bedwetting becomes stiff in Bsa. The medical term does not need to be interpreted in detail, just add the information in parentheses as an explanation of the word incontinence.

While the translation produced by Tradukka still maintains the medical term "incontinence" in Bsa. What makes translation from Tradukka less accurate is from its grammatical arrangement, where the word "managed" is not interpreted into Bsa, but only translates more successfully on Bsa.

\section{Acceptance}

The second assessment of translation quality can be seen in terms of its acceptance. It is said that the translation is acceptable if the translation in Bsa is more directed to the prevalence and naturalness which has been adjusted to the norms and rules in Bsa.

1. Acceptable

A translation is said to be acceptable if the translation feels natural and sounds familiar to readers both in terms of words, phrases, and sentences that have been adapted to the norms and rules contained in the Code with an average value of 2.6 to 3 . Here is an example Acceptable data from Tradukka:

Table 5. Acceptable data table from Tradukka

\begin{tabular}{ll}
\hline \multicolumn{1}{c}{ Bsu } & \multicolumn{3}{c}{ BsaTradukka } \\
\hline Data 11/Bsu/Art/20 & Data 11/Bsa/Trd/20 \\
The Foundation has also joined forces & $\begin{array}{l}\text { Yayasan telah juga bergabung dengan } \\
\text { with the Australian College of Midwives }\end{array}$ \\
$\begin{array}{l}\text { Akademi Australia bidan (20) untuk } \\
\text { (20) to develop an online course for } \\
\text { midwives. }\end{array}$ & $\begin{array}{l}\text { mengembangkan kursus online untuk } \\
\text { bidan. }\end{array}$ \\
\hline
\end{tabular}

Tradukka translates into the target language more acceptable and have a good readability. The word "foundation" is translated into the target language "yayasan", which means more acceptable and all readers better understand its meaning. 


\section{Unacceptable}

Inaccurate translations lead to translations that feel less natural and less familiar to the reader both in terms of words, phrases, and sentences that have been adapted to the norms and rules contained in the Code.

Table 6. Less acceptable on SDL Free Translate

\begin{tabular}{ll}
\hline Bsa & Bsu SDL Free Translate \\
\hline Data 7/Bsu/Art/15 & Data 7/Bsa/FT/15 \\
She said incontinence should not be & $\begin{array}{l}\text { Ia berkata dengan mengompol seharusnya } \\
\text { regarded as a normal part of }\end{array}$ tidak dianggap sebagai bagian dari \\
childbirth (15) and women needed to kelahiran (15) dan perempuan yang \\
prioritise their pelvic floor health.
\end{tabular}

The translation of "incontinence" presented to Bsa is interpreted as mengompol making the translation feel natural and feels stiff in the delivery of the message. The word mengompol seems to be translated literally and the reader will better understand the meaning than maintaining a foreign medical term. But in Bsa the resulting translation becomes less natural and does not see cultural norms or rules in Bsa. It will be more natural if the translation still maintains foreign terms. Whereas in the Tradukka translation there are 19 data that are not as acceptable as the example below:

Table 7. Less acceptable to Tradukka

\begin{tabular}{|c|c|}
\hline Bsa & Bsu SDL Free Translate \\
\hline Data 3/Bsu/Art/5 & Data 3/Bsa/Trd/4 \\
\hline Data $3 / \mathrm{Bsu} / \mathrm{Art} / 6$ & Data 3/Bsa/Trd/6 \\
\hline Data 3/Bsu/Art/7 & Data 3/Bsa/Trd/7 \\
\hline $\begin{array}{l}\text { A study of } 1000 \text { Australia mums (5) and } \\
\text { mums-to-be found (6) that despite } \\
\text { being in a high risk category for } \\
\text { developing incontinence, } 98 \text { per cent }\end{array}$ & $\begin{array}{l}\text { Sebuah studi } 1000 \text { Australia ibu(5) dan } \\
\text { ibu-to-be menemukan(6) bahwa meskipun } \\
\text { berada dalam kategori risiko tinggi untuk } \\
\text { mengembangkan inkontinensia, } 98 \text { persen }\end{array}$ \\
\hline $\begin{array}{l}\text { failed to do the daily recommended level } \\
\text { of pelvic floor exercises (7). }\end{array}$ & $\begin{array}{l}\text { gagal untuk melakukan tingkat } \\
\text { direkomendasikan harian latihan dasar } \\
\text { panggul(7). }\end{array}$ \\
\hline
\end{tabular}

From the table above Bsu can be seen "mums-to-be found" interpreted as ibu-tobe menemukan, the translation feels less natural because it is not translated grammatically into Bsa. The word to be is not translated so as to make the message delivered less acceptable.

\section{Readability}

The last level of assessment to find out the quality of the translation is legibility, where to measure and find out the level of readability distributed questionnaires to respondents where the quality concerns aspects of readability and legibility. The aspect of readability involves qualitative and quantitative changes in the transfer of information in the source language so that the viewer can understand it, while legibility refers to the appearance (appearance) of the text.

\section{Surakarta English and Literature Journal}




\section{High Readability}

Based on the assessment of a number of questionnaires obtained translation which on average has a high level of legibility because in words, terms, technical, phrases, clause and sentences the translation can be easily understood by the reader. For example, high readability can be described in the table below:

Table 8. Translation with a high level of Readability by, SDL free and Tradukka

\begin{tabular}{lrll}
\hline \multicolumn{2}{c}{ Bsu } & \multicolumn{1}{c}{ Bsa SDL Free Translate } & \multicolumn{1}{c}{ BsaTradukka } \\
\hline Data 26/Bsu/Art/34 & Data 26/Bsa/FT/34 & Data 26/Bsa/Trd/34 \\
By 2030, the & Pada tahun 2030, angka & 2030, prevalensi \\
prevalence & is & diperkirakan akan & diperkirakanakan meningkat \\
estimated & to & meningkat menjadi 6,5 juta & menjadi 6,5juta Australia. (34) \\
increase to $\mathbf{6 . 5}$ & Australia.(34) & \\
million Australians. & & \\
$(\mathbf{3 4 )}$ & & & \\
\hline
\end{tabular}

From the table data above, SDL is free even though there is no additional information on the object, the target audience is not too affected by the quality of the object, they still understand the message delivered to Bsa. More succinctly the translation produced by Tradukka, there are omissions of prepositions such as Pada tahun and the word orang, even so, the target readers are still able to understand the message conveyed.

From the data table above, SDL free although there is no additional information on the object, the target reader is not too affected by the quality of the BSA, they still understand the message conveyed to the BSA. For a more concise translation produced by Tradukka, there are omissions of prepositions such as "One Year" and the word "people", however, the target readers are still able to understand the message conveyed.

2. Medium Readability

The next quality discussion is moderate readability with an average rating of 2 to 2.5. Just like the discussion of accuracy and acceptability, it is not much different from legibility readability, where the translation produced by SDL free has 28 data, 16 data in Tradukka translation with moderate readability assessment. The following is a discussion of medium legibility:

Table 9. Translation with medium readability on SDL Free and Tradukka

\begin{tabular}{|c|c|c|}
\hline Bsu & Bsa SDL Free Translate & BsaTradukka \\
\hline $\begin{array}{l}\text { Data } \\
\text { 18/Bsu/Art/27 }\end{array}$ & Data 18/Bsa/FT/27 & Data $18 / \mathrm{Bsa} / \mathrm{Trd} / 27$ \\
\hline $\begin{array}{l}\text { The prevalence } \\
\text { of incontinence } \\
\text { was greater for } \\
\text { women who had } \\
\text { had multiple } \\
\text { births, with } 80 \\
\text { per cent of } \\
\text { women with three } \\
\text { or more children } \\
\text { experiencing }\end{array}$ & $\begin{array}{l}\text { Prevalensi mengompol } \\
\text { adalah lebih besar bagi } \\
\text { perempuan yang mempunyai } \\
\text { beberapa kelahiran, dengan } \\
80 \text { persen wanita dengan } \\
\text { tiga atau lebih anak-anak } \\
\text { mengalami kebocoran yang } \\
\text { tidak diinginkan.(27) }\end{array}$ & $\begin{array}{l}\text { Prevalensiin kontinensia adalah } \\
\text { lebih besar bagi perempuan } \\
\text { yang telah memiliki kelahiran } \\
\text { kembar, dengan } 80 \text { persen } \\
\text { wanita dengan tiga atau lebih } \\
\text { anak-anak yang mengalami } \\
\text { kebocoran yang tidak } \\
\text { diinginkan.(27) }\end{array}$ \\
\hline
\end{tabular}


unwanted

leakage (27).

Of the three data above, the entire text has a medium level of readability. This can be seen from the translation produced by Tradukka, "80 percent of women with three or more children experience unwanted leakage". The translation of the phrase "unwanted leakage" is indeed easy to understand but the target reader must repeat it up to two or even more in understanding the contents of the message delivered to Bsa. In the arrangement of the target language order, SDL Free translates literally plural sentences into Bsa, children are interpreted as children, said Incontinence also means to wet the bed. SDL Free and Tradukka also mean the same thing. In essence, the two online translations above have almost the same results in the translation. The target audience is able to understand the message delivered but they must repeat the reading to understand the message delivered to Bsa.

\section{Impact of Translation Quality}

Tradukka translation quality still has a better level than SDL Free Translate translation. In terms of the quality of acceptability, Tradukka almost has better quality even though the data accepting less than the data is less acceptable. This is different from the translation quality of SDL Free Translation, in terms of accuracy, acceptability and very low readability which ultimately results in less quality translation.

However, it is undeniable that even though advanced technology offers online translation and is cost effective, in terms of the translation, it still has drawbacks, compared to translations translated manually by human services.

The impact of this study is the level of quality comparison produced, in terms of accuracy, acceptability, and legibility. Although in the era of technology that is growing rapidly, which makes it easy for users of translation to surf in cyberspace, it needs to be ascertained and aware of the quality of the translation produced. Funds that are almost unused, the speed of the results obtained, up to a very short time make translator users prefer to use online services in translating. Therefore, a policy is needed regarding improving the quality of the resulting translation. A license from a survey institution can also complement and make an online translation service have its own assessment. The absence of suggestions and criticisms on the translation site makes the lack of quality values included in the translation produced.

\section{CONCLUSION}

From the results of Tradukka's research, it was in a better position in the quality of translation compared to SDL Free Translate. This is based on research findings with an average value of accuracy of $11.3 \%$, with an average percentage value of $7.5 \%, 15$ accurate data, 15 data is less accurate, for the acceptance of 20 acceptable data and 19 data is less acceptable, 13 data has high readability and 16 data have medium readability. The last position is occupied by SDL Free Translate, with an average percentage of $6.5 \%$ and only 2 data in each assessment of the quality of accuracy, acceptability and high readability. While 28 data are included into inaccurate, less acceptable and had a medium level of readability.

Even though in the era of technology that is growing rapidly, which makes it easy for translation users to surf in cyberspace, but it needs to be ascertained and watch out for the quality of the translations produced. Funds that are almost unused, the speed

\section{Surakarta English and Literature Journal}


of results obtained, up to a very short time make translator users prefer to use online services in translating. Therefore, a policy is needed regarding improving the quality of the translation produced. A license from a survey institution can also complement and make online translation services have its own assessment. The lack of opening of suggestions and criticisms on the translation site makes the lack of inclusion of quality values in the translations produced.

\section{REFERENCES}

Arifatun, Novia (2012). Kesalahan Penerjemahan Teks Bahasa Indonesia ke Bahasa Arab Melalui Google Translate (StudiAnalisisSintaksis). Journal of Arabic Learning and Teaching vol.1, no.1. Retrieved $20^{\text {th }}$ August 2019 in the URL: file:///C:/Users/toshiba/Downloads/1506-Article\%20Text-2888-1-1020130627.pdf

Hannah Dahlen. (2012).Vaginal Birth After Caesarean. Retrieved $4^{\text {th }}$ July 2017. In the URL:http://www.birthpool.net.au/birth-choices/vbac/vbac-articles/vaginalbirth-after-caesarean.shtml

Horwood, Ellis. (1986). Series in Computers and Theirs Applications. Chichester UK: Ellis Horwood Press.

Hutchin. John. (1995). Mechine Translation: A Brief History. Oxford: Pergamon Press

Oktaria Cn, Ika. (2018). Comparison Of Translation Quality Between Google Translate, Sdl Free Translation And Tradukka In The Health Article Entitled Vaginal Birth After Caesarean. ELLiC Proceedings Vol. 2, 2018

Larson, Mildred L. 1984. Meaning-Based Translation: A Guide to Cross-Language Equivalent. America: University Press of America.

Nababan, M.R. (2003). Teori menerjemahkan bahasa Inggris. Yogyakarta: PustakaPelajar.

Nababan, M., Nuraeni, A., \&Sumardiono. (2010). Pengembangan Model Penilaian Kualitas Terjemahan. Kajian Linguistik dan Sastra, Vol. 24, No. 1, Juni2012 , 39-57.

Prakosa, Bima. (2016). An Analysis on Translation Technique and Translation Quality Of Medical Terms In An Article Entitled "Critical Illness Due To 2009 A / H1n1 Influenza In Pregnant And Postpartum Women: Population Based Cohort Study "Produced By Google Translate. Surakarta University

Sujaini, Herry. (2014). Mesin Penerjemah Situs Berita Online Bahasa Indonesia ke Bahasa Melayu Pontianak. ELKHA Journal Vol. 06. No. 02. Retrived $20^{\text {th }}$ \begin{tabular}{llll}
\hline August 2019. & In & the
\end{tabular} file:///C:/Users/toshiba/Downloads/Documents/9098-29470-1-PB.pdf

Rahardjo, Mudjia. (2017). Studi Kasus Dalam Penelitian Kualitatif. Malang: UIN Mulana Malik Ibrahim. 